\title{
Spermatozoa in the Demanian system of free-living marine nematode Admirandus multicavus (Enoplida: Oncholaimidae)
}

\author{
V.V. Yushin, L.A. Gliznutsa
}

\begin{abstract}
A.V. Zhirmunsky National Scientific Center of Marine Biology, Far Eastern Branch, Russian Academy of Sciences, Palchevskogo Str. 17, Vladivostok 690041, Russia.

E-mails: vvyushin@yandex.ru (corresponding author); lyubovgliznutsa@mail.ru
\end{abstract}

\begin{abstract}
The process of insemination and fertilization in the nematode family Oncholaimidae is of interest because females of many species have extremely unusual sperm storage organ called "Demanian system". The mature spermatozoa from the main duct of the Demanian system of the free-living marine nematode Admirandus multicavus (Enoplida: Oncholaimidae) were studied by the transmission electron microscopy. The main duct is an epithelial tube with thick basal lamina. The dilated part of the duct is occupied by cluster of densely packed spermatozoa $7-8 \mu \mathrm{m}$ in size, while the narrow part contains occasional strongly elongated sperm cells. The centre of spermatozoa is occupied by a nucleus with poorly condensed chromatin surrounded by a distinct nuclear envelope, the presence of which confirms isolation of enoplids from all other clades of nematodes. The prevalent components of sperm cytoplasm are 'membranous organelles' (MO) which resemble strongly elongated thread-like osmiophilic cisternae densely packed into bundles. Small numerous mitochondria are interspersed between bundles of MOs. Spermatozoa form pseudopods that reflect putative amoeboid cell motility. Amorphous nucleus, threadlike MOs, and numerous minute mitochondria are likely to represent preadaptation to squeezing through the narrow tubular communications of the Demanian system. Present observations of $A$. multicavus support basic characters of the oncholaimid sperm pattern previously described in another oncholaimid species Pontonema vulgare.

How to cite this article: Yushin V.V., Gliznutsa L.A. 2021. Spermatozoa in the Demanian system of free-living marine nematode Admirandus multicavus (Enoplida: Oncholaimidae) // Invert. Zool. Vol.18. No.3. P.369-383. doi: 10.15298/invertzool.18.3.10
\end{abstract}

KEY WORDS: free-living marine nematodes, insemination, membranous organelles, nuclear envelope, Pontonema vulgare, pseudopod, spermatheca, spermatogenesis.

\section{Сперматозоиды в демановской системе свободноживущей морской нематоды Admirandus multicavus (Enoplida: Oncholaimidae)}

\author{
В.В. Юшин, Л.А. Глизнуца
}

Национальный научный чентр морской биологии им. А.В. Жирмунского ДВО РАН, ул. Пальчевского 17, Владивосток 690041, Россия. E-mails:vvyushin@yandex.ru; lyubovgliznutsa@mail.ru

The paper is devoted to 70th anniversary of Prof. V.V. Malakhov.

Статья посвящена 70-летию со дня рождения проф., акад. В.В. Малахова. 
РЕЗЮМЕ: Семейство нематод Oncholaimidae интересно с точки зрения процессов осеменения и оплодотворения, поскольку у самок многих видов описан уникальный семяприемник, названный «демановской системой». С помощью трансмиссионной электронной микроскопии были изучены зрелые сперматозоиды из главного протока демановской системы самки свободноживущей морской нематоды Admirandus multicavus (Enoplida: Oncholaimidae). Проток представляет собой эпителиальную трубку с толстой базальной пластинкой. Расширенный участок протока заполнен плотно упакованными сперматозоидами размером 7-8 мкм, а узкая часть содержит отдельные удлиненные сперматозоиды. В центре сперматозоидов располагается ядро с неконденсированным хроматином, окруженным ядерной оболочкой, наличие которой подтверждает изоляцию эноплид от всех остальных клад нематод. Основной компонент цитоплазмы сперматозоидов - «мембранные органеллы» (МО), имеющие вид нитевидных осмиофильных цистерн, плотно упакованных в пучки. Небольшие, но многочисленные митохондрии рассеяны между пучками МО. Сперматозоиды формируют псевдоподии, что отражает вероятную амебоидную подвижность клетки. Аморфное ядро, нитевидные МО и мелкие митохондрии можно объяснить преадаптацией сперматозоидов к продвижению через узкие трубчатые коммуникации демановской системы. Данные по A. multicavus подтвердили базовые характеристики онхолаймидного паттерна сперматозоидов, впервые описанного у другой онхолаймиды Pontonema vulgare.

Как цитировать эту статью: Yushin V.V., Gliznutsa L.A. 2021. Spermatozoa in the Demanian system of free-living marine nematode Admirandus multicavus (Enoplida: Oncholaimidae) // Invert. Zool. Vol.18. No.3. P.369-383. doi: 10.15298/invertzool.18.3.10

КЛЮЧЕВЫЕ СЛОВА: свободноживущие морские нематоды, инсеминация, мембранные органеллы, ядерная оболочка, Pontonema vulgare, псевдоподия, сперматека, сперматогенез.

\section{Introduction}

Data on sperm structure and spermatogenesis are known to be informative to elucidate phylogenetic relations of many metazoans (Baccetti, 1985; Jamieson et al., 1995; Liana, Witalinski, 2005; Reunov, 2005; Schmidt-Rhaesa, 2007; Dallai et al., 2016; Bakhoum et al., 2017). Spermatozoon morphology and development have also been studied for taxonomic and phylogenetic analyses of nematodes (Foor, 1970; Anya, 1976; Baccetti et al., 1983; Justine, 2002; Yushin, Malakhov, 2004; Slos et al., 2020).

The nematode spermatozoon represents an aberrant type of male gametes (Reunov, 2005). They are characterised by the absence of an axoneme, an acrosome and, with exception of members of the order Enoplida, a nuclear enve- lope (Justine, 2002; Yushin, Malakhov, 2004, 2014). The basic type of nematode spermatozoon may be described as a bipolar amoeboid cell with anterior pseudopod and posterior main cell body (MCB) (Justine, 2002; Yushin, Malakhov, 2014). The MCB has a condensed nucleus surrounded by mitochondria and so-called membranous organelles (MO). These unique organelles are characteristic of most nematode spermatozoa (Justine, 2002; Yushin, Malakhov, 2014). As it was previously shown, MOs in many nematodes are derived from Golgi bodies and appear as parts of complexes with fibrous bodies (FB) (MO-FB complexes). The bipartite complexes dissociate during late spermiogenesis into $i$ ) separate MOs that move to the cell periphery, attach to the spermatozoon plasma membrane, and open to the exterior via pores, and ii) free FBs, which transform into the cy- 
toskeleton of the pseudopod (Justine, Jamieson, 1999; Justine, 2002).

In the classification of nematodes proposed by De Ley and Blaxter (2002) and adapted in this study, the phylum Nematoda is subdivided into the classes Enoplea and Chromadorea. The description of spermatozoon structure and development is usually applied to the extensive order Rhabditida and several other orders of the nematode class Chromadorea (Yushin, Malakhov, 2014; Slos et al., 2020). The class Enoplea includes two well defined subclasses Enoplia and Dorylaimia where the former includes the order Enoplida that shows unusual structural diversity of male gametes (Justine, Jamieson, 1999; Yushin, Malakhov, 1999, 2014; Justine, 2002; Yushin, 2003; Afanasiev-Grigoriev, Yushin, 2009). The nucleus of the enoplid spermatozoa has a nuclear envelope, while spermatozoa from all other nematodes studied to date always lack such an envelope (Yushin, Malakhov, 2014). A characteristic feature of spermatogenesis in many enoplids is the absence of FBs in spermatogenous cells. When FBs do occur, they never associate with MOs as complexes, i.e., FBs and MOs develop separately and asynchronously (Yushin, Malakhov, 2004, 2014).

The unusual diversity of patterns of male gamete formation and structure did not allow for developing general principles of spermatogenesis in the order Enoplida. However additional studies on the enoplid sperm diversity could be helpful for comparative analysis of nematode male gametes. One of the unique patterns of the enoplid spermatogenesis was described in $P$. vulgare (Bastian, 1865) Filipjev, 1916 as the representative of the family Oncholaimidae (suborder Oncholaimina) (Yushin et al., 2002). In addition for the reconstitution of a nuclear envelope, the spermatogenesis of this enoplid is characterized by separate development of simplified cup-like MOs and large sole FB. The central part of the sperm stored in the male seminal vesicle contains a star-like nucleus with nuclear envelope and poorly condensed chromatin. The immature spermatozoa from the female gonoduct of $P$. vulgare have not been observed. Unusual sperm characteristics of $P$. vulgare warrant additional studies in order to understand fully oncholaimid sperm pattern. In this study, we report results of electron microscopy examination of spermatozoa in the female gonoduct of one more species of Oncholaimidae Admirandus multicavus Belogurov et Belogurova, 1979.

The basic female reproductive system in nematodes consists of two opposite branches, each subdividing into three main parts: $i$ ) ovary; ii) oviduct and iii) uterus (Smol et al., 2014). Uteri merge to vulva that functions both for insemination and egg deposition. Male impregnates female through a vulva into a uterus where sperm needs to be transported to the joining point with oviduct where ovulation and fertilization occur. Spermatozoa are stored in the female gonoduct for a long time before meeting with mature oocytes. The sperm storage sometimes lacks morphological specializations; however many nematodes have a spermatheca in the form of the clearly segregated part of the distal uterus (Decraemer et al., 2014).

The process of insemination and fertilization in the family Oncholaimidae is of interest because females of many species have an extremely unusual sperm storage called "Demanian system" (Rachor, 1969; Belogurov, Belogurova, 1989; Smol et al., 2014). In the genera Adoncholaimus and Admirandus Demanian system is represented by a long epithelial main duct running inside the body cavity parallel to the intestine and both branches of the female gonoduct (Fig. 1A). Anterior part of the duct, ductus entericus, connects to the intestine through osmosium (Belogurov, Belogurova, 1989). Posteriorly, the main duct extends to anal region where it branches into short canals terminating with slit-like terminal pores in the cloacal region. The main duct also connects by two short ductus uterinus to distal ends of both uteri exactly where the uterus merges with oviduct.

Spermatozoa have been observed in Demanian system of many species of oncholaimids (Rachor, 1969). At the level of the ducti uterini (if present), the main duct is usually dilated due 


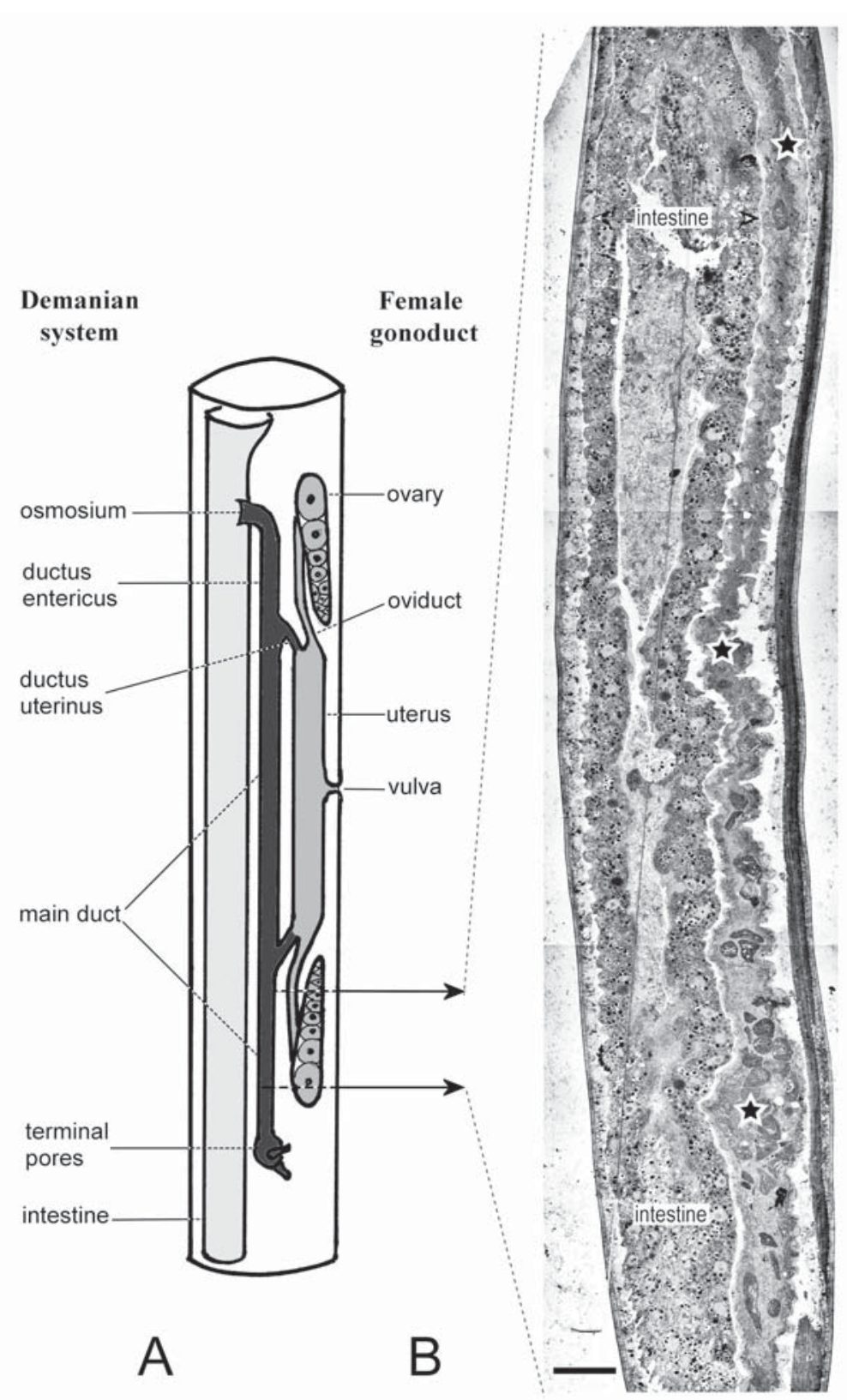

Fig. 1. A - highly simplified scheme of the Adoncholaimus type of Demanian system, redrawing based on Fig. 28 from Rachor (1969); arrows and dotted lines mark the part of the female body and Demanian system observed in Admirandus multicavus. B - TEM, overview of the longitudinal section through Admirandus multicavus female showing the main duct of Demanian system (asterisks) running along the intestine. Scale bar: $20 \mu \mathrm{m}$.

Рис. 1. А - упрощенная схема адонхолаймидного типа демановской системы, рисунок на основе рис. 28 из Rachor (1969) с изменениями; стрелки и пунктирные линии показывают изученный участок тела самки и демановской системы Admirandus multicavus; В - TEM, общий вид продольного среза самки Admirandus multicavus, на котором виден главный проток демановской системы (звездочки), идущий вдоль кишечника. Масштаб: 20 мкм. 
to accumulation of spermatozoa into dense clusters. Unlike other nematodes that are inseminated through a vulva, the females of oncholaimids may be impregnated by males through the terminal pores positioning at the cloaca, i.e. very far from vulva and uteri (Coomans et al., 1988). In these cases, sperm needs to be transported anteriorly from the tail region to the points of fertilization (uterus) through a very long and narrow system of ducts of the Demanian system.

The Demanian system is not well understood as a morphological phenomenon. However numerous observations of the whole mount specimens (Rachor, 1969) strongly suggest that but one of its functions is a sperm storage analogous to spermatheca or seminal receptacle. Presence of spermatozoa in the Demanian system has been demonstrated unequivocally only once by electron microscopy in the oncholaimid Adoncholaimus fuscus (Calcoen, Dekegel, 1979). However, that study contained little information on spermatozoan ultrastructure in this species.

The goal of the present study was to detect spermatozoa inside the Demanian system of the oncholaimid A. multicavus and describe their ultrastructure. New information clearly describes the pattern of oncholaimid spermatozoa in comparison with spermatozoa of other enoplids and nematodes in general.

\section{Material and methods}

Gravid females of Admirandus multicavus Belogurov et Belogurova, 1979 were extracted from samples of sandy mud in August 2001 at a depth of $1 \mathrm{~m}$ in the Vostok Bay, the Sea of Japan. Before fixation for transmission electron microscopy (TEM), the head and tail of one female were removed to facilitate the subsequent tissue fixation and embedding processes. The specimen was fixed $4 \mathrm{~h}$ at $4{ }^{\circ} \mathrm{C}$ in $2.5 \%$ glutaraldehyde in $0.05 \mathrm{M}$ cacodylate buffer with $21 \mathrm{mg} \mathrm{ml}^{-1}$ $\mathrm{NaCl}, 0.5 \mathrm{mg} \mathrm{ml}^{-1} \mathrm{MgCl}_{2}, 1 \%$ dimethylsulphoxide (DMSO). After aldehyde fixation, the specimen was cut again to extract the part of the body containing ovary, oviduct and uterus. This specimen was rinsed in the same buffer without
DMSO and post-fixed in $1.3 \%$ osmium tetroxide in a buffer containing $23 \mathrm{mg} \mathrm{ml}^{-1} \mathrm{NaCl}$. The specimens were dehydrated in ethanol followed by isopropanol series and embedded in Spurr resin. Thin longitudinal sections were made with a diamond knife using Leica UC6 ultramicrotome, stained with uranyl acetate and lead citrate, and examined with Zeiss Sigma 300 VP electron microscope.

\section{Results}

Longitudinal sectioning of the dorsal sector of the animal piece that contained female gonoduct reveals a structure of the Demanian system's main duct (Figs 1B; 2A). The duct is an epithelial tube with cell apexes facing inward to the duct lumen while the basal lamina envelopes the duct and borders with the body cavity (Figs 2B; 3A). Basal lamina appears as a pale homogenous layer of remarkable thickness (about 0.4$0.6 \mu \mathrm{m}$ ) along the part of the main duct which was observed (Figs 2B; 3A; 6A). The duct epithelium is thick and multicellular, the nuclei of the epithelial cells are not flattened and contain nucleoli (Figs 2B; 3A).

Strongly dilated part of the Demanian system's main duct contains a cluster of densely packed electron-dense polygonal cells with average size $7-8 \mu \mathrm{m}$ identified as spermatozoa (Fig. 2A, B). The duct dilatation gradually narrows into a long sinuous tube, which also contains spermatozoa as occasional cells or as chains of several cells (Fig. 3A). These individual spermatozoa are squeezed by narrow lumen of the duct and, as a result, could be strongly elongated up to $20 \mu \mathrm{m}$.

The internal structure of spermatozoa is obscure at low magnifications but enlargement shows clear arrangement of cell components characteristic of nematode spermatozoa. The centre of spermatozoa is occupied by the nucleus that, unlike many other nematodes and metazoans, is poorly condensed and does not have constant uniform outlines (Figs 2B; 3A, B; 4A, $\mathrm{C} ; 7)$. The nuclear chromatin presented by a sparse filamentous material of moderate density is surrounded by a distinct continuous nuclear 


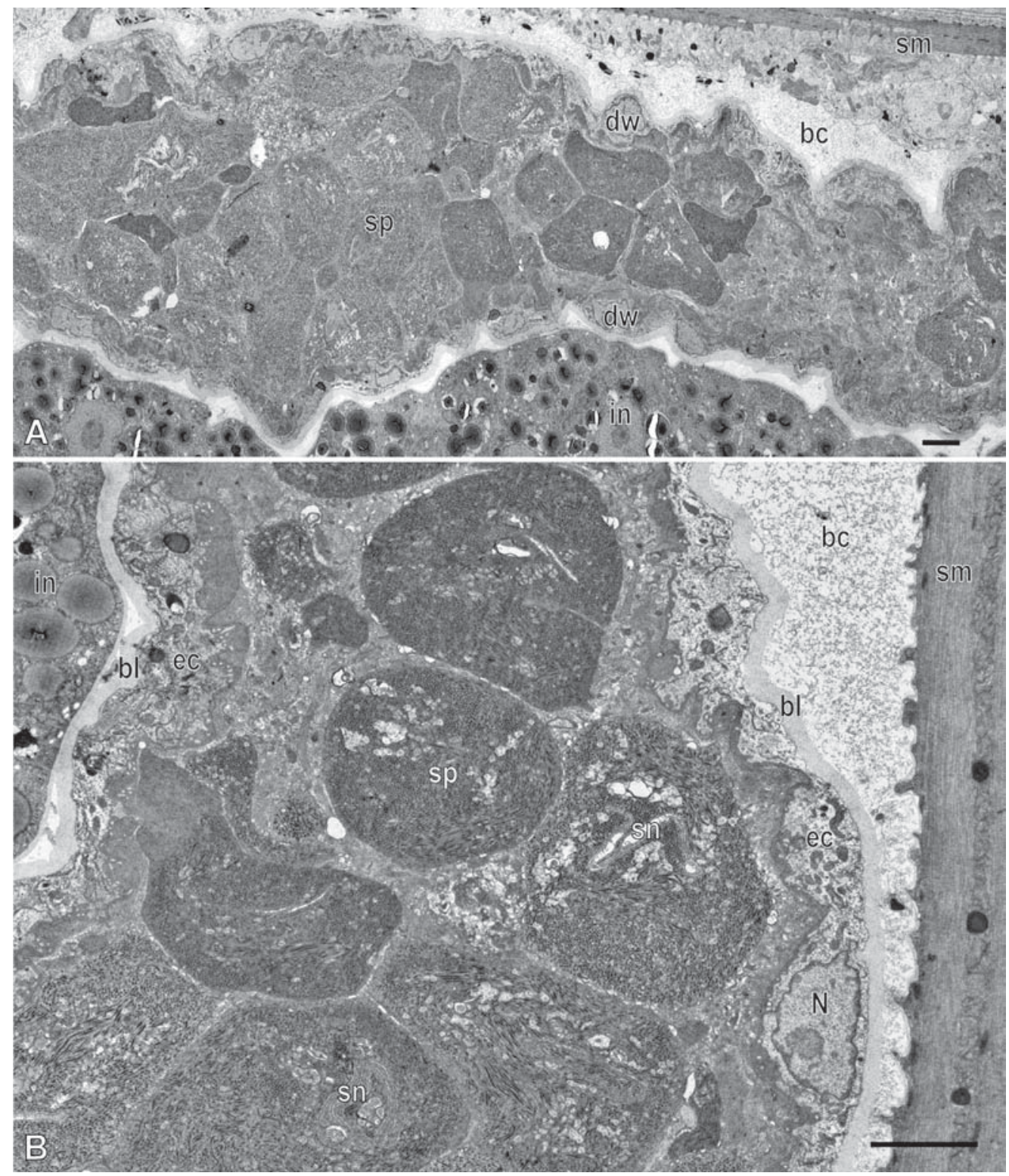

Fig. 2. Admirandus multicavus female, longitudinal section of the main duct of Demanian system, TEM. A overview of the duct dilated by the cluster of spermatozoa; B - dilated part of the duct at higher magnification.

Abbreviations: bc — body cavity; bl — basal lamina of the duct; dw - wall of the duct; ec — epithelial cell of the duct; in — intestine; $\mathrm{N}$ - epithelial cell nucleus; $\mathrm{sm}$ - somatic muscles; sn — sperm nucleus; sp — spermatozoon. Scale bars: $3 \mu \mathrm{m}$.

Рис. 2. Самка Admirandus multicavus, продольный срез главного протока демановской системы, ТЭМ. А - обзор скопления сперматозоидов в расширенной части протока; В - расширенная часть протока на большем увеличении.

Обозначения: $\mathrm{bc}$ - полость тела; $\mathrm{bl}$ - базальная пластинка протока; $\mathrm{dw}$ - стенка протока; ec - эпителиальная клетка протока; in - кишечник; $\mathrm{N}$ - ядро эпителиальной клетки; sm - соматическая мускулатура; sn — ядро сперматозоида; sp - сперматозоид. Масштаб: 3 мкм. 


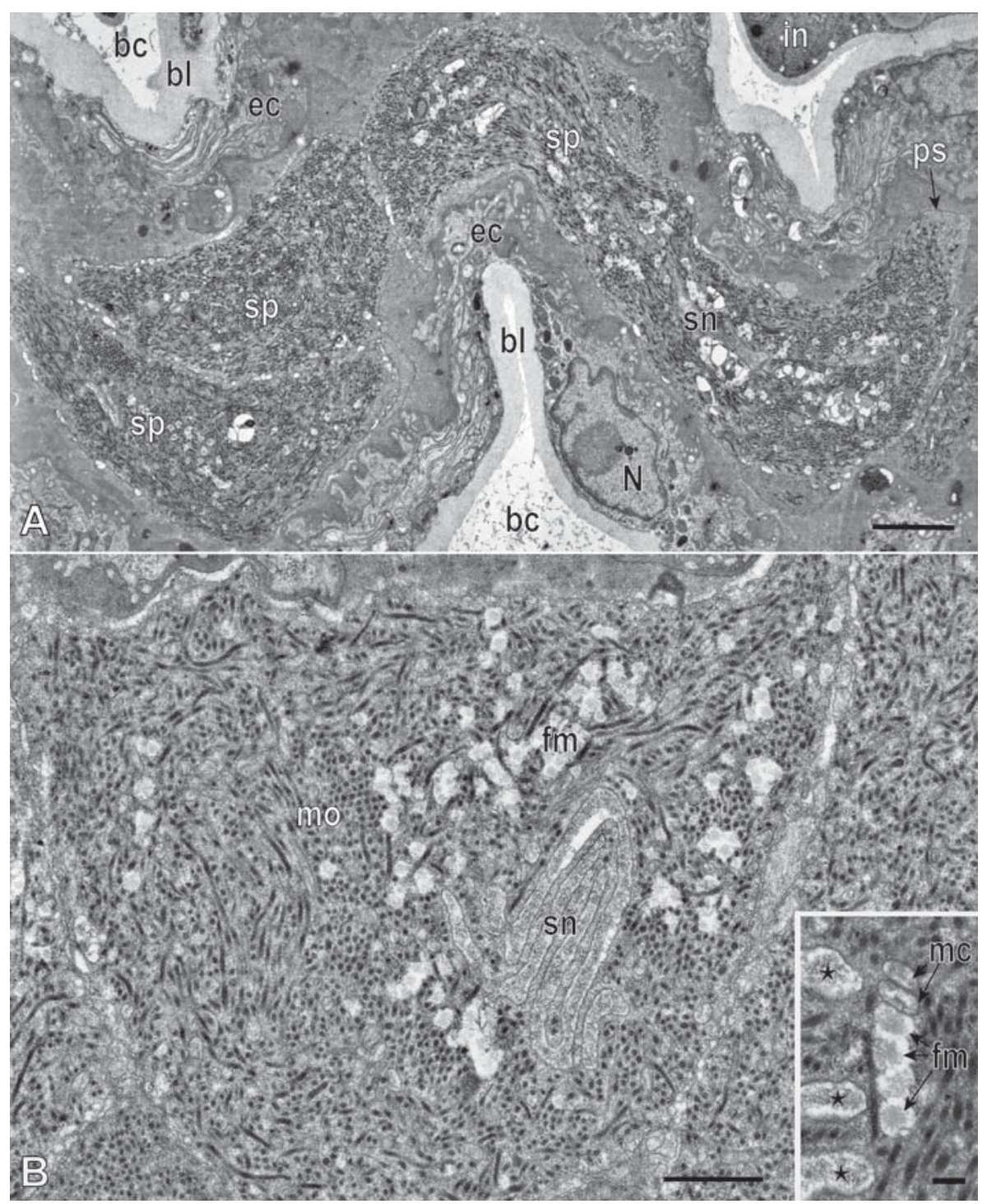

Fig. 3. Admirandus multicavus female, longitudinal section of the main duct of the Demanian system, TEM. A - longitudinal section of the narrow part of the duct with the chain of elongated spermatozoa; B spermatozoon from the cluster in the dilated part of the duct, overview (inset: flocculent material inside the space between membranous organelles; asterisks mark folds of the sperm nucleus). Abbreviations: bc body cavity; bl — basal lamina of the duct; ec — epithelial cell of the duct; fm - flocculent material; in intestine; $\mathrm{mc}$ - mitochondria; mo - membranous organelles; $\mathrm{N}$ - epithelial cell nucleus; $\mathrm{ps}$ - pseudopod; sn - sperm nucleus; sp - spermatozoon. Scale bars: A $-2 \mu \mathrm{m} ; \mathrm{B}-1 \mu \mathrm{m}$ (inset $-0.2 \mu \mathrm{m}$ ).

Рис. 3. Самка Admirandus multicavus, продольный срез главного протока демановской системы, ТЭМ. A - продольный срез узкой части протока с цепочкой удлиненных сперматозоидов; В - сперматозоид из скопления в расширенной части протока, обзор (врезка: хлопьевидный материал в пространстве между мембранными органеллами; звёздочками отмечены складки ядра сперматозоида). Обозначения: bc - полость тела; bl — базальная пластинка протока; еc - эпителиальная клетка протока; $\mathrm{fm}$ - хлопьевидный материал; in — кишечник; mc — митохондрии; то - мембранные органеллы; $\mathrm{N}$ - ядро эпителиальной клетки; ps - псевдоподия; sn - ядро сперматозоида; sp - сперматозоид. Масштаб: А - 2 мкм; В - 1 мкм (врезка - 0,2 мкм). 

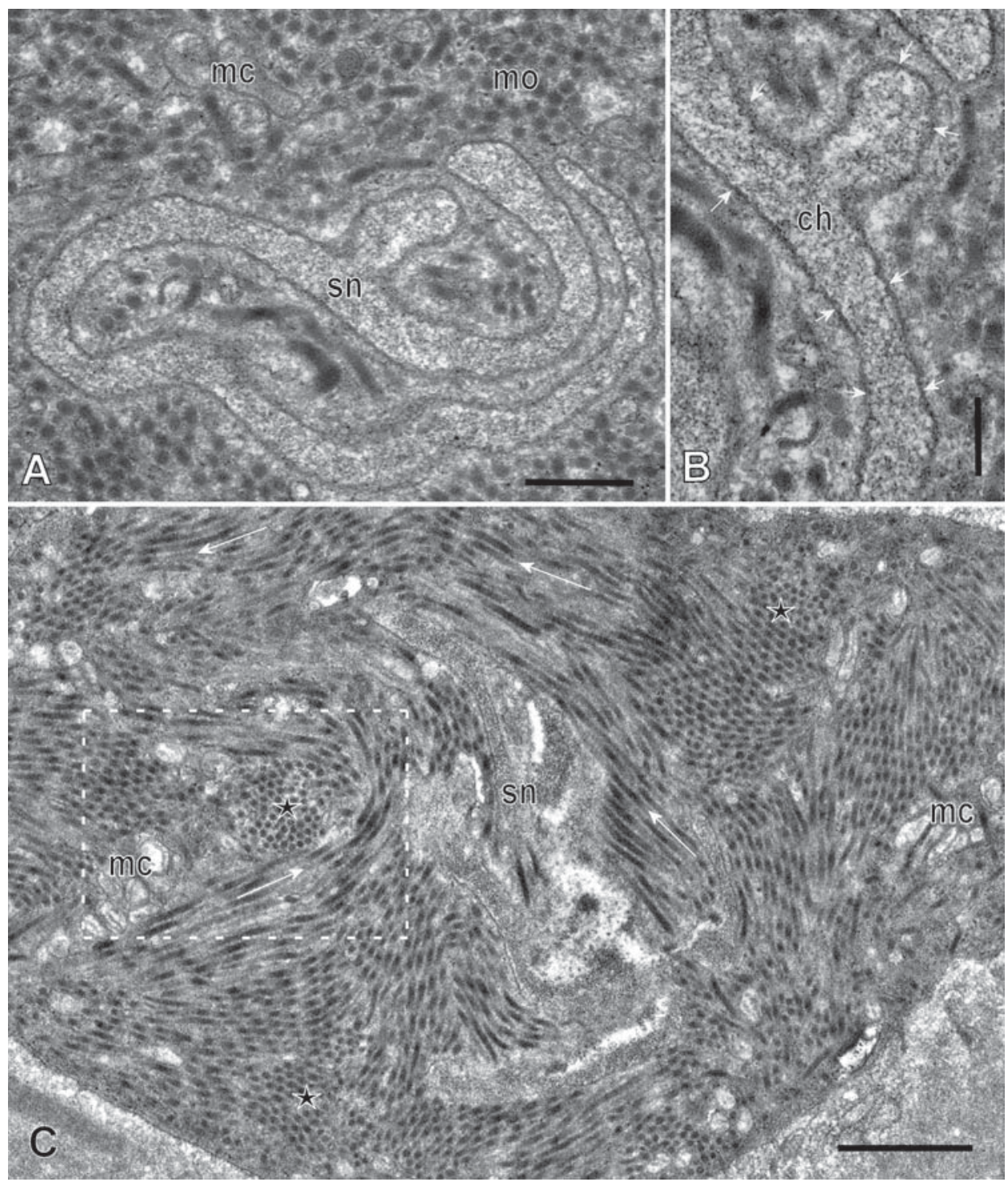

Fig. 4. Admirandus multicavus female, spermatozoa in the main duct of Demanian system, TEM. A — the central part of spermatozoon with nucleus foldings; B - higher magnification of the nucleus for demonstration of nuclear chromatin (ch) and nuclear envelop (white arrows); $\mathrm{C}$ - spermatozoon filled with bundles of membranous organelles; cross and longitudinal sections of the bundles are marked by asterisks and arrows respectively; the dotted rectangle borders the area shown at higher magnification as Fig. 5A. Abbreviations: $\mathrm{ch}$ - nuclear chromatin; $\mathrm{mc}$ - mitochondria; mo - membranous organelles; $\mathrm{sn}$ - sperm nucleus. Scale bars: $\mathrm{A}-0.5 \mu \mathrm{m} ; \mathrm{B}-0.25 \mu \mathrm{m} ; \mathrm{C}-1 \mu \mathrm{m}$.

Рис. 4. Самка Admirandus multicavus, сперматозоиды в главном протоке демановской системы, ТЭМ. A - центральная часть сперматозоида со складками ядра; В - ядро на большом увеличении для демонстрации ядерного хроматина (ch) и ядерной оболочки (белые стрелки); C - сперматозоид, заполненный пучками мембранных органелл; поперечные и продольные срезы пучков обозначены звездочками и стрелками соответственно; пунктирный прямоугольник показывает участок, показанный на большом увеличении на рис. 5А.

Обозначения: ch - ядерный хроматин; mс - митохондрии; mо - мембранные органеллы; sn - ядро сперматозоида. Масштаб: А $-0,5$ мкм; В $-0,25$ мкм; С - 1 мкм. 
envelope (Fig. 4B). The sperm nuclei appear to be easily reshaping. Sometimes they are extremely flattened to form whorls, stacks and long protuberances (Figs 3B; 4A, C). Transparent spaces filled with pale flocculent material are observed around the nuclei of many spermatozoa (Fig. 3B with inset).

The prevalent components of the voluminous sperm cytoplasm surrounding nuclei are dark stained cisternae (Figs 3B; 4C; 7), which we term here as 'membranous organelles' (MO) analogous to typical spheric MOs of other nematodes (see Introduction and Yushin, Malakhov, 2014). However, the MOs in A. multicavus sperm are thin and strongly elongated cisternae densely packed as parallel arrays into long thick bundles running in different directions inside the spermatozoon. As a result, cross, oblique and longitudinal profiles of bundles may be seen on the same section through spermatozoon (Figs 4C; 5A). Each MO that forms a bundle has osmiophilic homogenous content surrounded by a membrane (Fig. 5A, B). The MOs have a cross diameter only $50-60 \mathrm{~nm}$ and look like very thin threads (Fig. 5B, C). The total length of MOs has not been traced although occasional cisternae at least $2 \mu \mathrm{m}$ long were observed.

Less conspicuous than MOs but an important component of the spermatozoan cytoplasm are mitochondria (Figs 4A, C; 7). They have oval shape with length about $0.3-0.4 \mu \mathrm{m}$ and cross diameter about $0.1-0.2 \mu \mathrm{m}$ (Fig. 5A, B). Mitochondria are remarkably numerous; their total number seen on one section through spermatozoon may be more than 50 . The mitochondria are interspersed between the bundles of $\mathrm{MO}$ and form small clusters (Figs 4A, C; 5A).

The spermatozoa are capable of forming pseudopods as cell protrusions filled with filamentous matter, possibly of cytoskeleton nature (Figs 2A; 6A, B; 7). The polygonal spermatozoa forming the cluster in the dilated duct of the Demanian system demonstrate no distinct polarization except when they contact with the duct epithelium. Here spermatozoa form a short wide pseudopod anchoring to the apexes of the epithelial cells (Fig. 6A). Free elongated sper- matozoa found inside the narrow part of the duct are capable of forming prominent pseudopods (Fig. 6B), which likely reflect the amoeboid motility analogous to movable spermatozoa of many other nematodes (Yushin, Malakhov, 2014).

\section{Discussion}

The Demanian system does not have characteristics general for family Oncholaimidae; it varies from a complicated system of ducts to more simple structures or, sometimes, its total absence (Rachor, 1969; Belogurov, Belogurova, 1989). In many cases, the Demanian system contains clusters of spermatozoa and functionally may be considered as the overcomplicated spermatheca of enigmatic evolutionary origin. This was confirmed by TEM in the brief communication of Calcoen \& Dekegel (1979) who detected spermatozoa in the main duct of Adoncholaimus fuscus, which has Demanian system nearly identical to that of Admirandus multicavus. Our TEM observations of A. multicavus confirmed association of spermatozoa with Demanian system. The main duct of the Demanian system in A. multicavus appears as an epithelial tube reinforced by thick basal lamina maintaining shape and lumen of the duct for sperm storage and transportation. The spermatozoa assembled as a large cluster at the dilated part of the main duct anchor to the epithelial wall by pseudopods. This is similar to the observations made previously in uteri and spermathecae of many other nematodes (Lee, 1971; Wright et al., 1973; Van de Velde et al., 1991; Yushin, Malakhov, 1994; Yushin, 2003; Yushin, Zograf, 2004).

The spermatozoa in A. multicavus are relatively large amoeboid cells, which reach about $20 \mu \mathrm{m}$ in length during crawling inside the duct. Spermatozoa of many nematodes sometimes are even larger but, in most cases, these are cells about $5 \mu \mathrm{m}$ or less (Bird, Bird, 1991).

The spermatozoan nuclei of $A$. multicavus have a nuclear envelope which is easily seen due to poor condensation of a nuclear chromatin. Nuclear envelope usually is absent (secondarily 

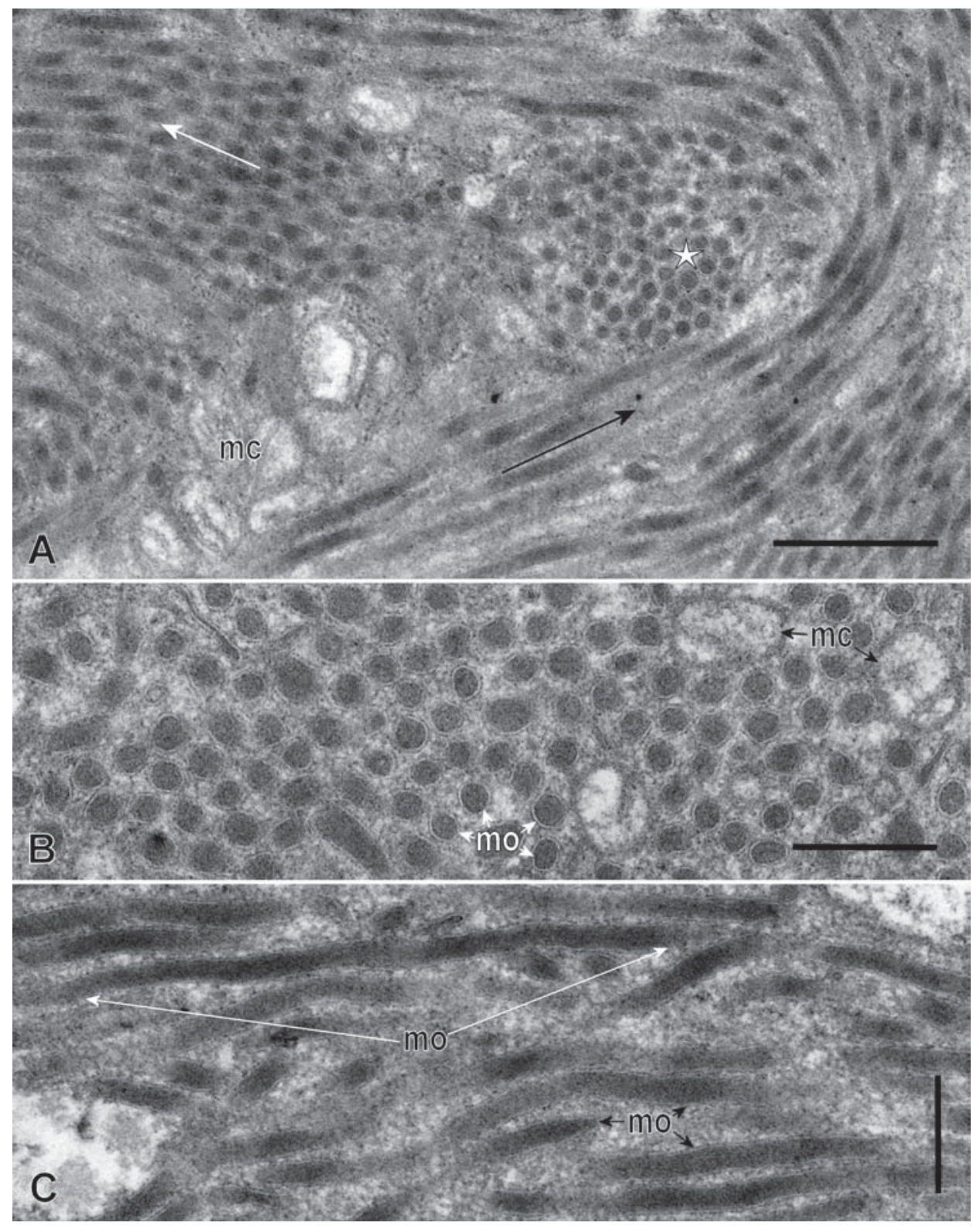

Fig. 5. Admirandus multicavus female, structure of spermatozoan membranous organelles, TEM. A higher magnification of the dotted rectangle on the Fig. 4B; cross (asterisk), longitudinal (black arrow) and oblique (white arrow) sections through the bundles of membranous organelles; $\mathrm{B}, \mathrm{C}$ - high magnification of cross (B) and longitudinal (C) sections of membranous organelles; osmiophilic content of organelles is bounded by distinct membrane.

Abbreviations: $\mathrm{mc}-$ mitochondria; mo - membranous organelles. Scale bars: A $-0.5 \mu \mathrm{m} ; \mathrm{B}, \mathrm{C}-0.25 \mu \mathrm{m}$.

Рис. 5. Самка Admirandus multicavus, строение мембранных органелл сперматозоидов, ТЭМ. А большое увеличение участка, обозначенного пунктирным прямоугольником на рис. 4В; поперечные (звездочка), продольные (черная стрелка) и косые (белая стрелка) срезы пучков мембранных органелл; В, С - большое увеличение поперечных (В) и продольных (С) срезов мембранных органелл; хорошо видна мембрана, окружающая осмиофильное содержимое органелл.

Обозначения: $\mathrm{mc}$ - митохондрии; то - мембранные органеллы. Масштаб: А $-0,5$ мкм; В, C - 0,25 мкм. 

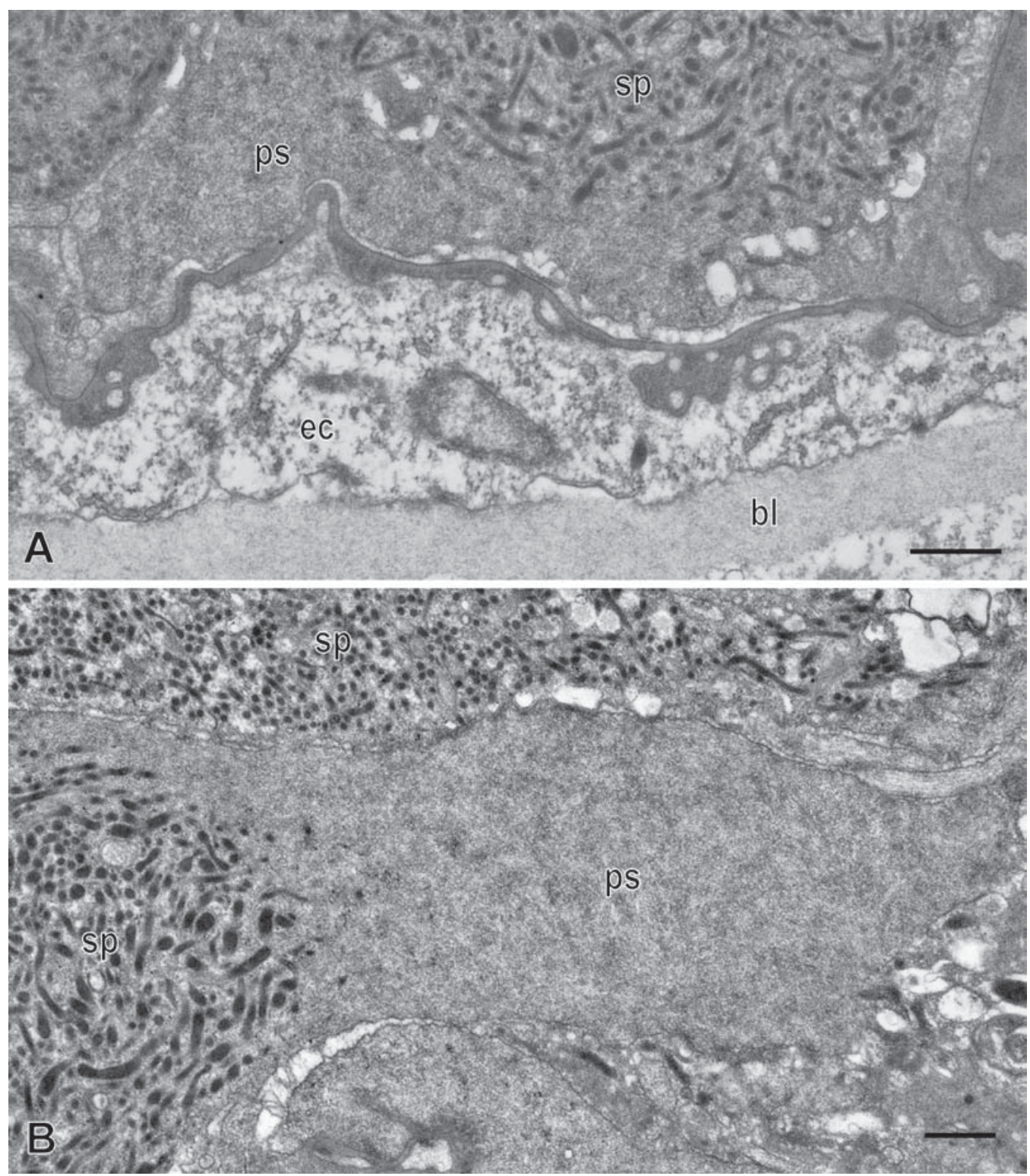

Fig. 6. Admirandus multicavus female, pseudopods of spermatozoa. TEM. A — pseudopod anchoring spermatozoon to the epithelium of the main duct of Demanian system; B - the pseudopod of spermatozoon crawling in the narrow part of the main duct of Demanian system.

Abbreviations: $\mathrm{bl}$ - basal lamina of the duct; ec — epithelial cell of the duct; $\mathrm{ps}$ - pseudopod; sp — spermatozoon. Scale bars: $0.5 \mu \mathrm{m}$.

Рис. 6. Самка Admirandus multicavus, псевдоподии сперматозоидов. ТЭМ. А - псевдоподия, прикрепляющая сперматозоид к эпителию главного протока демановской системы; В - псевдоподия сперматозоида, ползущего в узкой части главного протока демановской системы.

Обозначения: $\mathrm{bl}$ - базальная пластинка протока; ec - эпителиальная клетка протока; ps - псевдоподия; sp сперматозоид. Масштаб: 0,5 мкм. 


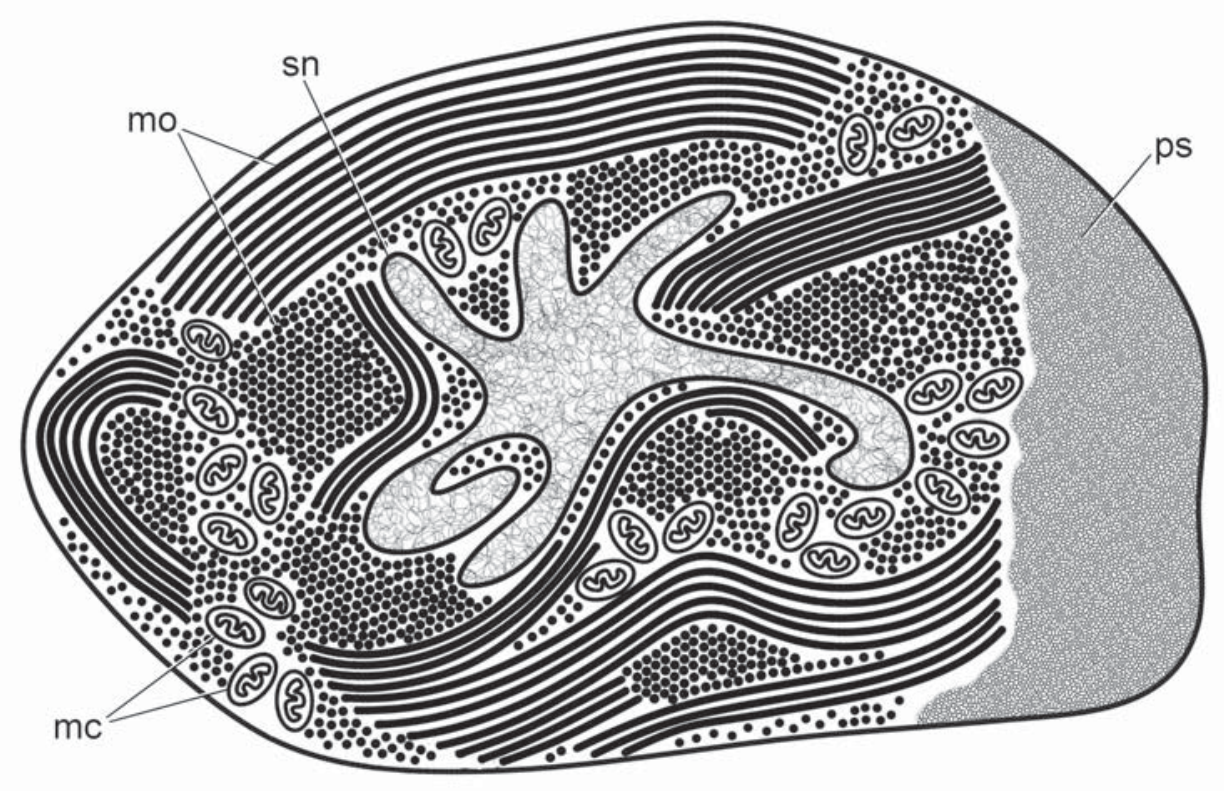

Fig. 7. Highly schematic representation of the spermatozoon from Demanian system of Admirandus multicavus; the central amorphous nucleus (sn) with nuclear envelope is surrounded by the bundles of membranous organelles (mo) and clusters of mitochondria (mc); each spermatozoon bears a pseudopod (ps). Not scaled.

Рис. 7. Схема строения сперматозоида из демановской системы Admirandus multicavus; центральное аморфное ядро (sn) с ядерной оболочкой окружено пучками мембранных органелл (mo) и группами митохондрий (mc); у каждого сперматозоида формируется псевдоподия (ps). Не масшабировано.

reduced) in the nematode spermatozoa, but for the order Enoplida it appears to be a mandatory sperm characteristics described in all enoplid taxa studied to date (Yushin, Malakhov, 2014). Possessing a nuclear envelope is considered as symplesiomorphic feature of the order. The unequivocal demonstration of nuclear envelope in the spermatozoa of $A$. multicavus confirms isolation of enoplids from all other clades of nematodes (Yushin, Malakhov, 2004; Bik et al., 2010; Blaxter, Koutsovoulos, 2015; Smythe et al., 2019).

Lacking constant shape is a remarkable feature of the sperm nucleus in A. multicavus. The spermatozoa seem to be capable of squeezing through a narrow lumen of ducts to reach the final destination, i.e. uterus. The nucleus, which also looks amoeboid, follows cell shaping easily because its nuclear chromatin does not condense into dense rigid globule $1-2 \mu \mathrm{m}$ in size, typical for metazoan spermatozoa (Baccetti, 1985). The thread-like MOs, which have never been observed before in nematodes, could be viewed as a suitable preadaptation to squeezing through extremely narrow spaces and openings. Finally, numerous but minute mitochondria appear to be functionally fit for moving through narrow spaces. Thus, special characteristics of the mature spermatozoa of $A$. multicavus make it fit well for transportation and movement inside the long narrow tubular communications of the Demanian system.

To a certain extent, the spermatozoa found in the Demanian system of $A$. multicavus may be considered as a mature or activated spermatozoa because they bear pseudopods and, presumably, are capable of locomotion inside the female gonoduct (Shepherd, 1981). However, these spermatozoa have intact MOs, which do not associate with the sperm outer membrane 
and have no openings to exterior, as in the case of mature spermatozoa of other nematodes (Yushin, Malakhov, 2014). It is very possible that the osmiophilic content of MOs of $\mathrm{A}$. $\mathrm{mul}$ ticavus is released when spermatozoa pass all ducts of the Demanian system to occupy position in the distal uterus where fertilization of ovulated oocytes occurs. It means that pseudopods bearing spermatozoa have not finalized their development (spermiogenesis).

Immature spermatozoa in testes have been described in detail in studies of spermatogenesis in another oncholaimid species Pontonema vulgare (Yushin et al., 2002). The spermatozoa of both oncholaimid species may be compared easily to show basic similarities. These include amorphous nucleus with poorly condensed chromatin surrounded by distinct nuclear envelope, simple MOs with osmiophilic content (variable vesicles in $P$. vulgare and thread-like cisternae in $A$. multicavus). The filopodia of $P$. vulgare and the pseudopods of $A$. multicavus spermatozoa reflect usual physiological differences between immature and mature sperm respectively (Justine, 2002).

Despite formal similarities in simplified structure of MOs, both species apparently have different images of spermatozoa due to $\mathrm{MO}$ shape and abundance (compare fig 17C in Yushin at al., 2002 and Fig. 7 in present paper). In $P$. vulgare MOs are numerous but separate components are embedded in the filamentous matrix (Yushin et al., 2002). In A. multicavus the sperm cytoplasm is nearly identical to the mass of densely packed MOs, where only occasional or clustered mitochondria are interspersed. This easily seen difference in spermatozoa likely reflects relatively distant position of two species inside the family Oncholaimidae where $A$. multicavus presents subfamily Adoncholaiminae Gerlach et Riemann, 1974 with mostly complicated Demanian system, while $P$. vulgare presents Pontonematinae Gerlach et Riemann, 1974 where this system is totally absent (Smol et al. 2014).

Our observations of $A$. multicavus showed for the first time detailed spermatozoon structure in the female gonoduct in the oncholaimid nematodes and confirmed the basic features of the oncholaimid sperm pattern described previously in P. vulgare (Yushin et al., 2002). Presence of nuclear envelope in spermatozoa of both species is an important symplesiomorphic characteristics uniting all enoplid nematodes. Amorphous nucleus, poor condensation of nuclear chromatin together with simplified MOs, may be presumably considered as the apomorphic ultrastructural features characteristic of Oncholaimidae. Studies of sperm development in testes of A. multicavus together with observations of mature spermatozoa from the uterus of $P$. vulgare could be fruitful for precise delineation of the oncholaimid sperm pattern for future comparative analysis. However, at the level of subfamilies, the spermatozoa of oncholaimids demonstrate easily detectable ultrastructural differences which may reflect differences in modes of insemination and gonoduct architecture such as Demanian system.

The sperm life inside the ducts of the exotic Demanian system is a curious topic for naturalistic observations of oncholaimid nematodes such as $A$. multicavus but, unfortunately, it is not sufficient for evolutionary analysis of enoplids and other nematodes. The Godfather of the nematode phylogeny Ivan Filipjev wrote in his fundamental book: "Мне кажется вообще затруднительным придавать какое-либо морфологическое значение органам столь явно вторичного происхождения, развитым притом у столь небольшой группы, как Oncholaimini" (It seems difficult to me to see any morphological significance in organs of clearly secondary origin, especially when present in such a small group as Oncholaimini) (Filipjev, 1921, transl. from Russian by Alexei Sharov).

Acknowledgements. The reported study was funded by RFBR according to the research projects 20-04-00569-a and 00-04-48896-a. The authors are grateful for technical assistance to D.V. Fomin of Far East Center of Electron Microscopy (NSCMB, Vladivostok). The authors are grateful to Alexei F. Sharov (Fisheries and Boating Services Department of Natural Resources, Annapolis, MD, USA) for the linguistic revision of the text. 


\section{References}

Afanasiev-Grigoriev A.G., Yushin V.V. 2009. Electron microscopic study of spermiogenesis in the free-living marine nematode Leptosomatides marinae Platonova 1976 (Enoplida: Leptosomatidae) // Russ. J. Mar. Biol. Vol.35. P.156-163.

Anya A.O. 1976. Physiological aspects of reproduction in nematodes // Adv. Parasitol. Vol.14. P.267-351.

Baccetti B. 1985. Evolution of the sperm cell // C.B. Metz, A. Monroy (eds.). Biology of fertilization.Vol.2. Orlando, USA: Academic Press. P.3-58

Baccetti B., Dallai R., Grimaldi de Zio S., Marinari A. 1983. The evolution of the nematode spermatozoon // Gamete Res. Vol.8. P.309-323.

Bakhoum A.J.S., Miquel J., Ndiaye P.I., Justine J.-L., Falchi A., Bâ C.T., Marchand B., Quilichini Y. 2017. Advances in spermatological characters in the Digenea: Review and proposal of spermatozoa models and their phylogenetic importance// Adv. Parasitol. Vol.98. P.111-165. doi: 10.1016/bs.apar.2017.04.001

Belogurov O.I., Belogurova L.S. 1989. Morphology and systematics of free-living Oncholaimidae (Nematoda: Enoplida: Oncholaimina) // Asian Marine Biology. Vol.6. P.31-58.

Bik H.M., Lambshead P.J., Thomas W.K., Lunt D.H. 2010. Moving towards a complete molecular framework of the Nematoda: a focus on the Enoplida and early-branching clades // BMC Evolutionary Biology. Vol.10. Article number 353. doi: 10.1186/1471-214810-353.

Bird A.F., Bird J. 1991. The Structure of Nematodes. San Diego: Academic Press. 316 p.

Blaxter M., Koutsovoulos G. 2015. The evolution of parasitism in Nematoda // Parasitology. Vol.142. Suppl.1. P.S26-S39. doi: 10.1017/S0031182014000791

Calcoen J.A., Dekegel D. 1979. Spermatozoa in the demanian organ of female Adoncholaimus fuscus (Bastian, 1965) (Nematoda) // Neth. J. Zool. Vol.29. P.142143.

Coomans A., Verschuren D., Vanderhaeghen R. 1988. The demanian system, traumatic insemination and reproductive strategy in Oncholaimus oxyuris Ditlevsen (Nematoda, Oncholaimina) // Zool. Scr. Vol.17. P.1523. doi:10.1111/j.1463-6409.1988.tb00083.x

Dallai R., Gottardo M., Beutel R.G. 2016. Structure and evolution of insect sperm: New interpretations in the age of phylogenomics // Annu. Rev. Entomol. Vol.61. P.1-23. doi:10.1146/annurev-ento-010715-023555

Decraemer W., Coomans A., Baldwin J. 2014. Morphology of Nematoda // A. Schmidt-Rhaesa (ed.). Gastrotricha, Cycloneuralia and Gnathifera. Vol.2. Nematoda. Berlin, Boston: De Gruyter. P.1-59.

De Ley P., Blaxter M.L. 2002. Systematic position and phylogeny // D.L. Lee (ed.). The Biology of Nematodes. London: Taylor \& Francis. P.1-30.

Filipjev I.N. 1921. [Free-living marine nematodes of the Sevastopol area] // Trudy Osoboi Zoologocheskoi Laboratorii i Sevastopol'skoi Biologicheskoi Stantsii
Rossiiskoi Akademii Nauk. Ser.2. No.4. P.351-614 [in Russian].

Foor W.E. 1970. Spermatozoon morphology and zygote formation in nematodes // Biol. Reprod. Vol.2 (Suppl.). P.177-202.

Jamieson B., Justine J.-L., Ausio J. 1995. Advances in spermatozoal phylogeny and taxonomy // Muséum National d'Histoire Naturelle. Vol.166. P.1-564.

Justine J.-L. 2002. Male and female gametes and fertilization // D.L. Lee (ed.) The Biology of Nematodes. London: Taylor \& Francis. P.73-119.

Justine J.-L., Jamieson B.G.M. 1999. Nematoda // B.G.M. Jamieson. (ed.). Reproductive Biology of Invertebrates. Vol.9. Part B. New Delhi: Oxford and IBH. P.183-266.

Lee D.L. 1971. The structure and development of the spermatozoon of Heterakis gallinarum (Nematoda) // J. Zool. Vol.164. P.181-187. doi:10.1111/j.14697998.1971.tb01304.x

Liana M., Witaliński W. 2005. Sperm structure and phylogeny of Astigmata // J. Morphol. Vol.265. P.318324. doi:10.1002/jmor.10361

Rachor E. 1969. Das de Mansche Organ der Oncholaimidae, eine genito-intestinale Verbindung bei Nematoden // Zeitschrift für Morphologie der Tiere. Bd.66. S.87-166. doi:10.1007/bf00277650

Reunov A.A. 2005. [Spermatogenesis in Multicellular Animals]. Moscow: Nauka. 123 p. [In Russian]

Schmidt-Rhaesa A. 2007. The evolution of ogan systems. Oxford: Oxford University. 385 p.

Shepherd A.M. 1981. Interpretation of sperm development in nematodes // Nematologica. Vol.27. P.122125.

Slos D., Yushin V.V., Claeys M., Ivanova E.S., Kosaka H., Bert W. 2020. Structure, development, and evolutive patterns of spermatozoa in rhabditid nematodes (Nematoda: Rhabditida) // J. Morphol. Vol.281. P.14111435.

Smol N., Muthumbi A., Sharma J. 2014. Order Enoplida // A. Schmidt-Rhaesa (ed.). Gastrotricha, Cycloneuralia and Gnathifera. Vol.2. Nematoda. Berlin, Boston: De Gruyter. P.193-249.

Smythe A.B., Holovachov O., Kocot K.M. 2019. Improved phylogenomic sampling of free-living nematodes enhances resolution of higher-level nematode phylogeny // BMC Evol. Biol. Vol.19. Article number 121. doi:10.1186/s12862-019-1444-X

Van de Velde M.-C., Coomans A., Van Ranst L., Kruger J.C.D., Claeys M. 1991. Ultrastructure of sperm cells in the female gonoduct of Xiphinema // Tissue Cell. Vol.23. P.881-891.

Wright K.A., Hope W.D., Jones N.O. 1973. The ultrastructure of the sperm of Deontostoma californicum, a free-living marine nematode // P. Helminthol. Soc. Wash. Vol.40. P.30-36.

Yushin V.V. 2003. Ultrastructure of spermatogenesis in the free-living marine nematode Anticoma possjetica (Enoplida, Anticomidae) // Nematology. Vol.5. P.777-788.

Yushin V.V., Coomans A., Malakhov V.V. 2002. Ultrastructure of spermatogenesis in the free-living marine 
nematode Pontonema vulgare (Enoplida, Oncholaimidae) // Can. J. Zool. Vol.80. P.1371-1382.

Yushin V.V., Malakhov V.V. 1994. Ultrastructure of sperm cells in the female gonoduct of free-living marine nematodes from genus Enoplus (Nematoda: Enoplida) // Fund. Appl. Nematol. Vol.17. P.513-519.

Yushin V.V., Malakhov V.V. 1999. Spermatozoa of nematodes of the order Enoplida have a nuclear envelope // Doklady Biological Sciences. Vol.367. P.395-397.

Yushin V.V., Malakhov V.V. 2004. Spermatogenesis and nematode phylogeny // R. Cook, D.J. Hunt (eds.). Nematology Monographs and Perspectives. Vol.2. Proceedings of the Fourth International Congress of
Nematology, June 2002, Tenerife, Spain. Leiden, The Netherlands: Brill. P.655-665.

Yushin V.V., Malakhov V.V. 2014. The origin of nematode sperm: Progenesis at the cellular level // Russ. J. Mar. Biol. Vol.40. P.71-81. doi:10.1134/ S1063074014020114

Yushin V.V., Zograf J.K. 2004. Ultrastructure of spermatozoa in the free-living marine nematode Paracanthonchus macrodon (Nematoda, Chromadorida) // Invertebr. Reprod. Dev. Vol.45. P.59-67. doi:10.1080/ 07924259.2004 .9652573

Responsible editor E.N. Temereva 